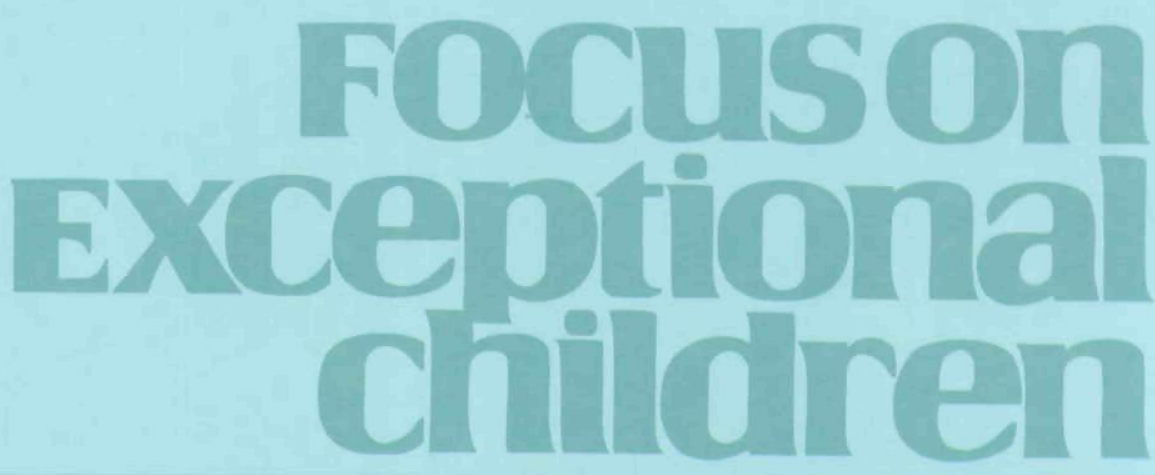

\title{
Federal Policy and the Education of Students with Disabilities: Progress and the Path Forward
}

\author{
Jane E. West and Peggy J. Schaefer Whitby
}

Federal policy has had a significant effect on the education of students with disabilities in the United States. From the Supreme Court cases of the 1970s to the No Child Left Behind Act (NCLB) accountability provisions of the early 21 st Century, students with disabilities, their families, and educators who work with them have been mightily shaped by the force of federal policy. While surely there are well documented unintended consequences - under-resourced requirements, unenforced mandates, and examples of poor implementation - there have also been significant milestones of progress. This article provides a 500,000 foot overview of some of the progress to date and some of the opportunities on the horizon. It presents evidenced-based outcomes of NCLB for students with disabilities and considers the path forward as we approach reauthorization of NCLB. We consider three specific areas of gains under NCLB for students with disabilities: awareness, access, and achievement.

\section{TOP TEN CONTRIBUTIONS OF FEDERAL POLICY TO DATE}

Below is a consideration of key contributions of federal policy beginning in the $1970 \mathrm{~s}$ that represent the cornerstones of progress.

\section{Zero Reject}

Zero reject is the principle that every school aged child, no matter how significant a disability he or she might have, is entitled to attend public school. Prior to 1975, when the first significant education legislation addressing students with disabilities was enacted (The Education for All Handicapped Children Act, PL 94-142 [EAHCA]), school districts and states were free to exclude students from school on the basis of their disability. Two landmark Supreme Court Cases challenged these practices. In 1972, Pennsylvania Association for Retarded Children (PARC) challenged the State of Pennsylvania for failing to provide access to education for all children with mental retardation $(P A R C, 1972)$. The result was a court order requiring the state to educate students with mental retardation in

Jane E. West is Senior Vice President for Policy, Programs and Professional Issues at the American Association of Colleges of Teacher Education. Peggy J. Schaefer Whitby is a doctoral candidate in the Department of Exceptional Education at the University of Central Florida.

This article is adapted from a speech given by Jane West in Milwaukee at the annual conference of the Teacher Education Division of the Council for Exceptional Children on their 50th Anniversary. 
a program as similar as possible to that provided to all other students. The second landmark case was Mills $v$. Washington DC Board of Education in 1972. Here parents brought a class action suit against the District of Columbia for failing to provide a publicly supported education for all children. The court ordered the District to include students with disabilities in their educational programs.

When Congress drafted the 1975 EAHCA, a core principle was that every child with a disability is entitled to a free appropriate public education. Neither schools, districts, nor states could turn students away from a public education because of their disability. This core principle of access is often taken for granted today. It is important to remember that there was a time, not so long ago in our nation's history, that it was not the case.

\section{Free Appropriate Public Education in the Least Restrictive Environment}

The key guarantee that IDEA makes to students with disabilities and their families is the provision of a free appropriate public education (FAPE) in the least restrictive

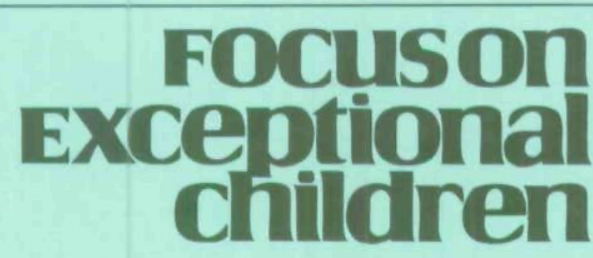

ISSN 0015-511X FOCUS ON EXCEPTIONAL CHILDREN (USPS 203-360) is published monthly except June. July, and August as a service to teachers, special educators, curriculum specialists, administrators, and those concerned with the special education of exceptional children. This publication is annotated and indexed by the ERIC Clearinghouse on Handicapped and Gifted Children for publication in the monthly Current Index to Journals in Education (CUE) and the quarterly index, Exceptional Children Education Resources (ECER). The full text of Focus on Exceptional Children is also available in the electronic versions of the Education Index. It is also available in microfilm from Serials Acquisitions, National Archive Publishing Company, P.O. Box 998, Ann Arbor, MI 48106-0998. Subscription rates: individual, \$42 per year; institutions, \$56 per year. Copyright (1) 2008, Love Publishing Company. All rights reserved. Reproduction in whole or part without written permission is prohibited. Printed in the United States of America. Periodical postage is paid at Denver, Colorado. POSTMASTER: Send address changes to:

Love Publishing Company

Executive and Editorial Office P.O. Box 22353

Denver, Colorado 80222

Telephone (303) 221-7333

\section{EDITORIAL BOARD}

Lisa Dieker
University of Central Florida
Marleen Pugach
University of Wisconsin-Milwaukee

environment (LRE). The concepts of FAPE and LRE have retained their prominence in the law since its inception. FAPE requires that public schools provide special education and related services at public expense; meet state standards; include an appropriate preschool, elementary, or secondary education in the state; and maintain conformity with the student's individualized education program (IEP). With its roots in the reasoning of the "separate is not equal" tenet of Brown v. Board of Education, the standard of least restrictive environment is intended to ensure that children with disabilities are educated, to the maximum extent "appropriate," with their nondisabled peers. According to IDEA, educating students in special classes or separate facilities should only occur when the nature or severity of the disability is such that education in general education classes, with the use of supplementary aids and services, cannot be satisfactorily achieved. Interpretations of the word "appropriate" have been confounding at times, with some arguing that a separate setting where only children with a particular disability are in school (such as a school for deaf students) is the most appropriate for those students. Often, the reason for this argument is that this is the only setting in which necessary services (such as sign language instruction) are available.

Despite a range of interpretations of LRE, the principle of including students in general education classrooms remains a firm commitment in both policy and practice. Over the years, there has been a notable increase of students with disabilities receiving instruction in general education classrooms. As Figure 1 demonstrates, the most recent data indicate that about $55 \%$ of students with disabilities participate in general education classrooms $80 \%$ or more of the school day and another $24 \%$ spend $40 \%$ to $79 \%$ of the day in general education classrooms. NCLB has had a positive effect on the inclusion of students with disabilities in general education classrooms, as will be discussed later in this article.

\section{Individualized Education Programs and the Role of Parents}

Another core element of the federal special education law since its inception has been the central role that parents play, particularly in developing the IEP. The IEP is a plan for instruction and services developed by a team, including the parents and the professionals who work with the student: the special education teacher, general education teachers, representatives of the school district, and professionals who may provide related services to the students (e.g., speech therapy, occupational therapy, and counseling). The plan is intended to address the unique disability-related needs of the student and to articulate the services and supports the student will receive as well as to assess the student's present level of functioning and progress goals. Parents are integral to this process and 


\section{Educational Environments of Students with Disabilities (Fall 2006)}

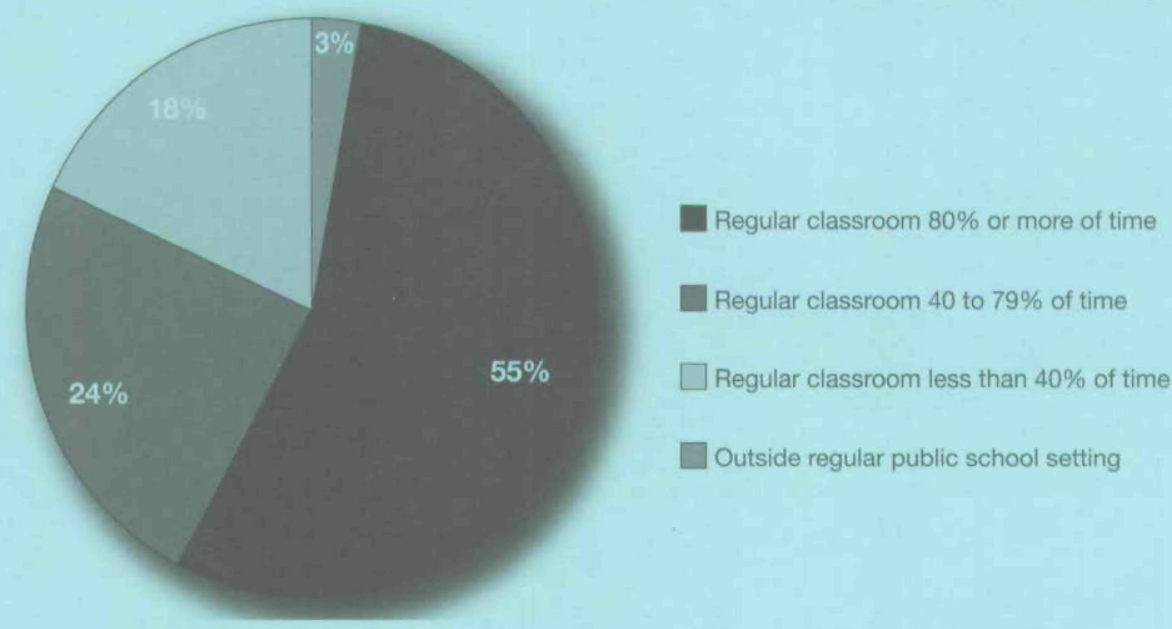

Source: EPE Research Center, 2008. Data from U.S. Department of Education, Office of Special Education Programs.

\section{FIGURE 1 \\ Placement}

must agree in writing to the plan if it is to move forward. This remarkable provision of IDEA has maintained an essential component of federal disability law - the acknowledgement that individuals have unique needs that must be addressed in order for them to participate on a level playing field.

\section{Civil Rights Protections}

The civil rights provisions of IDEA, Section 504 of the Rehabilitation Act (1974), and more recently the Americans with Disabilities Act (ADA) (1990) represent the key civil rights components of federal education policy for students with disabilities. Grounded in the equal protection provision of the Fourteenth Amendment to the Constitution, which guarantees equal access under the law, these federal laws form a safety net for students with disabilities and confer an obligation on society to affirmatively include students with disabilities by providing auxiliary aids and services. Section 504, which was enacted in 1974, prohibits discrimination in education (and many other areas) on the basis of disability when federal funds are involved and provides the right to reasonable accommodations in education. Likewise, the Americans with Disabilities Act prohibits discrimination in virtually all areas of public life and extends the antidiscrimination tenets in education into private schools. IDEA confers the right to an education to children with disabilities and their parents and details due process protections to guarantee those rights. Together these laws are intended to result in the participation and inclusion of students with disabilities in education arenas from birth to death and to require the aids and services needed in order to make access meaningful. For example, physical access to a history class for a deaf person may not allow her to have equal access. The provision of sign language interpretation or transcription may accomplish equal access. These civil rights laws envision access to a level playing field through the assurance of nondiscrimination and the provision of aids and services.

Due process protections for parents of children with disabilities are explicitly articulated in IDEA. A student's parents are entitled to notice of an action the school proposes to take, a hearing before an impartial hearing officer, an opportunity to present and rebut evidence, and the right to appeal a decision. The due process protections are modeled after those in other civil rights laws and are critical to parents' ability to exercise their right to FAPE for their child.

\section{Funding Stream for Education to States and Local School Districts}

The federal government has acknowledged that there is a cost in providing a level playing field for students with disabilities and has committed to paying a portion of it in IDEA. Since 1975, the federal government has made an annual contribution to educating students with disabilities through Part B, the state grant. IDEA Part B funding has increased significantly in recent years (from $\$ 2.3$ billion in 1995 to $\$ 10.9$ billion in 2008) (USDOE, 2008a), however, more is needed. 
In 1975, when IDEA was first enacted, Congress anticipated providing $40 \%$ of the excess cost of educating students with disabilities. At $\$ 10.9$ billion, the federal share now represents $17.2 \%$ of the cost. The all-time high for the federal share was $18.5 \%$ in FY 2005. States and local school districts have been picking up a substantial portion of the federal share and have become quite vocal with policy makers in advocating for the federal government to keep its promise. Indeed, President-elect Barrack Obama has promised to "fully fund" IDEA, as did his opponent, Sen. John McCain. Legislation to fully fund IDEA has been repeatedly considered by the Congress in the last decade and has always fallen short of the needed votes to secure the additional funding. Demands will continue as state and local governments increasingly face budget shortfalls.

\section{Multidisciplinary Approach}

From its inception, IDEA (1990, 1997, 2004) has acknowledged the need for a multidisciplinary approach to the provision of services for students with disabilities. It takes a team to plan for and address the needs of a student with disabilities. The IEP team is a group of individuals knowledgeable about the child's strengths and weaknesses who come together to develop a plan for the child. Depending upon the individual child's needs, the IEP Team may include related services personnel (a speech therapist, an occupational therapist, a school psychologist, a school social worker, etc.), an early childhood expert, a transition expert, a vocational rehabilitation counselor, a representative of a postsecondary program, a technology expert, the school principal, general education teachers, special education teachers, and others. This concept has stood the test of time and has been affirmed in practice as multiple professionals from many disciplines continue to work together to provide instruction and services to students with disabilities.

\section{Investment in Personnel}

Even before the predecessor law to IDEA was enacted in 1974 (EAHCA, 1974), the federal government provided funds to prepare specialized personnel to work with students with disabilities. When IDEA was first developed, provisions now called Part D were included to support the preparation of personnel, including special educators and related services personnel. The federal government has invested in the development of leadership for the field of special education by funding doctoral level study for experts who go on to become researchers, lead states and districts in special education, and become the preparers of the next generation of special education teachers and related services personnel. Funds are available to both institutions of higher education and state agencies. The federal government has always acknowledged that carrying out the requirements of the federal law will require a workforce uniquely prepared to do so. While the investment in personnel has remained stagnant at about $\$ 88$ million per year for the last several years for institutions of higher education and $\$ 48$ million per year for states, it is a significant resource for professional development.

\section{Investment in Infrastructure}

The investment in personnel is one component of the investment in an infrastructure to support the resources that go directly to states and local districts to provide services to students. The federal government has played a major role in the development and maintenance of this infrastructure, which includes investments in higher education, states, technical assistance providers, researchers, and parent education. Over the years, investments in model demonstration programs have led to system wide changes in areas of national need as they have developed. These areas include services to students with behavioral disorders, services for students transitioning from school to work or to postsecondary education, and more recently Responsiveness to Intervention (RTI), a tiered approach to instruction. The investment in parent education has yielded a nationwide state by state system of parent training and information centers that provide critical education and resources to parents. While the federal investment in this infrastructure has not been what it needs to be, it represents a critical national contribution, which has enabled remarkable progress for parents, professionals, and students over the last four decades.

\section{Access to the General Education Curriculum}

In the early years of federal policy, the primary goal of federal policy was physical access to schools. Federal policy clarified that states and districts could not bar students from entering the doors, enrolling in school, and participating in classes. Over the years the notion of access has evolved so that today we think of access in terms of outcomes. It is not enough to be allowed to participate; that participation must yield results. One of the cornerstones of this thinking is access to the general education curriculum.

For too long students with disabilities were taught in separate classes where there was little or no reference to the general education curriculum. Teachers were not prepared with knowledge of the general education curriculum. Special education was seen as primarily remedial, too often with little or no connection to what was occurring in general education classes. In 1997, IDEA began to require students with disabilities to have access to the general education curriculum. States were slow to implement this requirement, but increasingly there was an expectation for students with disabilities to be learning the same content (though perhaps not with the same depth and breadth) as students without disabilities. 
With the enactment of NCLB, this provision became central to the instruction of students with disabilities.

\section{Students With Disabilities as a Discreet Subgroup Under NCLB}

NCLB requires that students with disabilities be considered as a discreet subgroup. This means that, for the first time in our nation's history, data are reported about students with disabilities as a group, rather than as individuals. Achievement scores on statewide assessments are reported for the subgroup of students with disabilities so that they can be considered in relation to other subgroups and to the average score in particular grades and subjects (e.g., fourth grade math scores). While assessment of students with disabilities under NCLB has raised numerous challenges (e.g., accommodations policies that do not violate the validity of standardized tests; creating alternate assessments that are valid, reliable, and cost-effective to administer; aligning alternate assessments to grade level standards), the availability of these data offer a significant opportunity to consider the performance of students with disabilities in relation to their nondisabled peers.

The power of these data, as is considered below, invites reconsideration of the potential of students with disabilities. To what extent does the disability determine achievement level, as opposed to the provision of appropriate supports and services? Why might one state, district, or school demonstrate higher levels of achievement than another for students with the same disabilities?

These ten landmark accomplishments of federal education policy for students with disabilities provide a foundation for today's work in implementing and reforming NCLB. What follows is a more in-depth consideration of three key areas of progress for students with disabilities under NCLB since its enactment in 2001. These areas are awareness, access, and achievement.

\section{NCLB'S CONTRIBUTION TO THE AWARENESS OF STUDENTS WITH DISABILITIES}

It has been said that NCLB could do for the quality of public education what PL 94-142 has done for equal access to public education (Chubbs, 2005). According to the Commission on No Child Left Behind (2007), the most significant outcome of NCLB was to establish, as a national policy, the premise that all children can learn. Thus, one of the key contributions of NCLB for students with disabilities has been an expanded awareness of students with disabilities as learners.

The fact that the achievement scores of students with disabilities are a part of the accountability system represented a significant shift in school policies across the nation. Never before have individual school principals or district superintendents been accountable for the learning of students with disabilities. While they had historically been held accountable for their access to education and for compliance with IDEA, the notion of being accountable for their academic achievement represented a new watershed. No longer could the principal's focus be on compliance with IDEA; rather the principal now needed to see positive educational achievement for students with disabilities, as measured by the same standardized tests (for the most part) as other students.

An advocate in the report No Child Left Behind Act and the Individuals With Disabilities Act: A Progress Report described the impact of the assessment requirements and public reporting of the results for children with disabilities as follows: "People teach what is tested and who is testedso now that students with disabilities are included in the accountability system, they are being taught." (National Council on Disability [NCD], 2008).

The expectation that students with disabilities would achieve to the same level that students without disabilities achieve is a revolutionary expectation, and it is not surprising that it has been controversial. Indeed, many argued that holding students receiving special education services to the same achievement levels as students not receiving special education services was an oxymoron. A proposal from the state of Washington reflects this thinking. "Students who appropriately meet the eligibility criteria for receipt of special education and related services are, by definition, unable to reach $100 \%$ proficiency. If they were able to meet $100 \%$ proficiency they would be, by definition, ineligible for special education and related services" (Washington Department of Education, 2003).

Many responded to that argument by noting the fact that some students with disabilities were achieving at high levels (see next section on achievement) and by highlighting the fact that the majority of school-aged children in special education have a primary disability that is not related to their cognitive or intellectual functioning (Cortiella, 2007; West, 2005).

Figure 2 reveals that the vast majority of students with disabilities, about $85 \%$, are provided with special education services because of a disability that does not preclude them from achieving proficiency in a state's academic content standards in reading and math. Almost half of students who are served under IDEA are students with learning disabilities. Another $19 \%$ are students with speech or language impairments; $7.7 \%$ with emotional disturbance; $9.2 \%$ with other health impairments. Many researchers believe that students are often misclassified as having a learning disability when they struggle with reading. One report noted that "from its inception as a category, LD has served as a sociological sponge that attempts to wipe up general education's 


\section{Students Receiving Special Education Services by Disability Category}

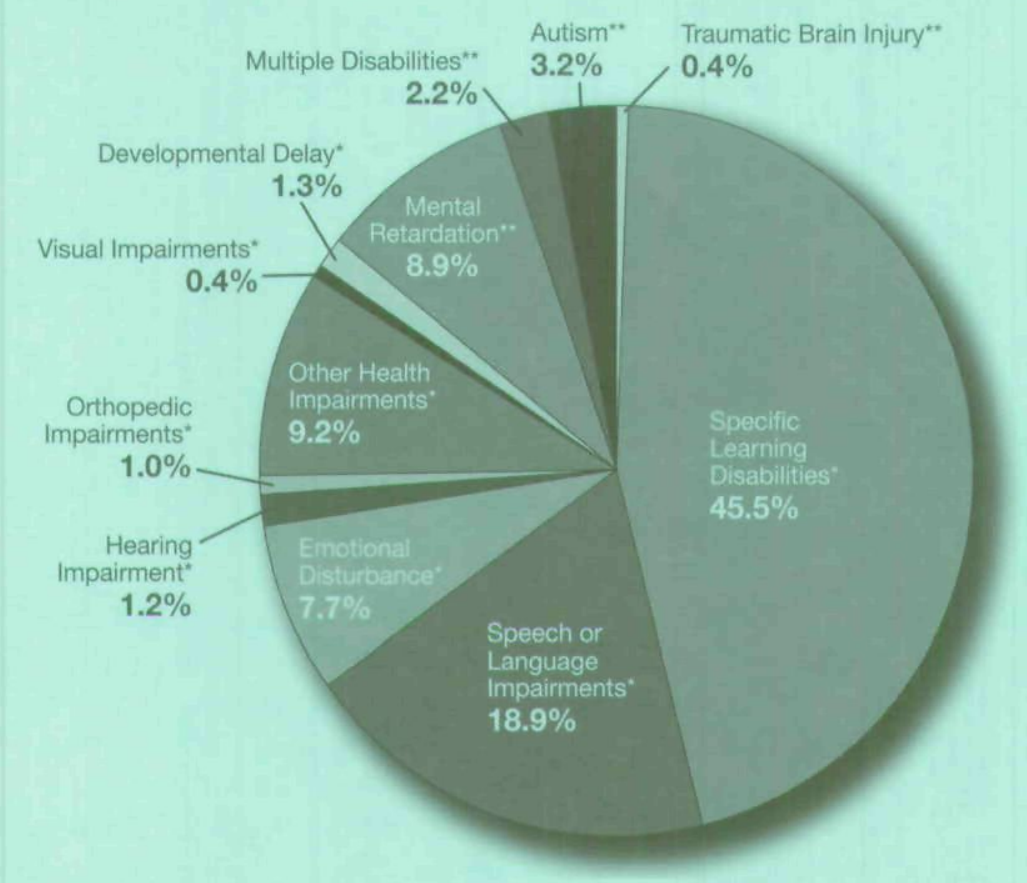

Source: Rewards \& Roadblocks: How Special Education Students are Faring Under No Child Left Behind (26), by C. Cortiella, 2007, New York: National Center for Learning Disabilities.

FIGURE 2

Disability Subgroups Served Under IDEA: Age 6-21

spills and cleanse its ills" (Finn, Rotherham, \& Hokanson, 2001). Indeed, Congress has demonstrated a similar concern through its enactment of provisions in IDEA that are intended to prevent students from needing special education services, such as "early intervening services" that allow IDEA funds to be used to intervene with students who are struggling but who do not yet require special education services.

Madeleine Will of the National Down Syndrome Society has suggested that accountability and disaggregation of subgroup data was the best thing to happen to students with disabilities (Commission on No Child Left Behind, 2007). Schools are no longer able to hide behind a group mean. Under NCLB, schools are required to disaggregate and report performance data and to create adequate yearly progress objectives for the following subgroups: economically disadvantaged students, students from major racial and ethnic groups, students with disabilities, and students with limited English proficiency (NCLB, 2002). According to the findings of the NCD (2008), the need to disaggregate the subgroup data and report subgroup data as a means to identify progress is widely accepted, despite resistance to this provision when NCLB was first implemented.

One of the undesirable consequences of NCLB has been that students with disabilities have been scapegoated for a school's poor performance (Cole, 2006). The NCLB Commission set out to examine the facts behind the allegation that students with disabilities were the cause of many schools not meeting AYP (Commission on No Child Left Behind, 2006). In fact, their research revealed that a very small percentage of schools were not making AYP solely because of students with disabilities. Furthermore, it unearthed the fact that large numbers of schools did not even report the performance of students with disabilities because the group did not reach the $\mathrm{N}$-size (the state-determined minimum number of students required to be in a subgroup for it to be counted). The report found that in California, only 28 schools, or $.4 \%$ of the total number of schools in California, did not make AYP solely because of students with disabilities. In Florida, of the schools that did not make AYP, only $2 \%$ were solely because of students with disabilities, accounting for $.7 \%$ of the total number of Florida 
schools. The allegation that students with disabilities were a primary cause of school failure was revealed as a myth. In addition, the Commission recommended more stringent accountability for students with disabilities by proposing that the $\mathrm{N}$-size be restricted to 20 students so that more students with disabilities would be captured by the accountability system. ${ }^{1}$

In summary, because of the NCLB requirement that students with disabilities be treated as a discreet subgroup, the general awareness of students with disabilities as a group of learners has increased. Students with disabilities are no longer undistinguished and part of an obscure "mean" that disguises disparities in achievement among distinct groups. This awareness has both raised expectations for the performance of students with disabilities and highlighted the progress that needs to be made.

\section{NCLB'S CONTRIBUTION TO ACCESS TO THE GENERAL EDUCATION CURRICULUM FOR STUDENTS WITH DISABILITIES}

Both NCLB (2001) and IDEA (1997) are explicit in expecting access to the general curriculum as the key to success for children with disabilities (Hardman \& Dawson, 2008). Increasing accountability for the achievement of all students and assuring adequate yearly progress is mandated by NCLB (Yell, Katsiyannas, \& Shiner, 2006). The increased accountability of NCLB has made it imperative that children have access to the general curriculum in order to make positive contributions to AYP.

The increase in the number of students with disabilities being served in general education classrooms (rather than in separate special education classrooms) has shown steady progress over the last several years. Children with mild disabilities who were previously educated in resource rooms or classrooms for students with varying exceptionalities are now being educated in less restrictive environments in order to meet accountability standards and highly qualified teacher standards (Twenty-Sixth Annual Report to Congress, 2004). Fifty-five percent of children with disabilities are served in the general education setting $80 \%$ of the time or more (See Figure 1). By moving students from specialized classrooms into general education environments, students have greater access to the general curriculum and are taught by a highly qualified teacher in the regular education environment (Yell,

\footnotetext{
' Regulations issued by the U.S. Department of Education on October 29, 2008 provided some limitations on the $\mathrm{N}$-group size that states may choose. The $\mathrm{N}$-size must now be "no larger than necessary to ensure the protection of privacy for individuals" and to ensure statistical reliability. The range of $\mathrm{N}$-sizes, prior to this regulation, had been from 5 to 75 .
}

Drasgow, \& Lowery, 2005), increasing the likelihood of passing standardized testing (Yell, Katsiyannas, \& Shiner, 2006). Since the 2001-2002 school year, an increasing number of students with disabilities are being served in less restrictive environments. Because students with disabilities who are served in general education classrooms are more likely to be taught by highly qualified teachers who have mastered the content area of instruction, the likelihood that they are exposed to the general education curriculum increases.

A second area of increased access resulting from NCLB has been an increase in participation in state- and districtwide assessments. NCLB was the first federal legislation to require all students to participate in state and district assessments (Rabinowitz, Sato, Case, Benitex, \& Jordon, 2008). Most children with disabilities participate in statewide general assessments, as indicated in Figure 3.

Increased participation since the enactment of NCLB is notable. For example, the state of West Virginia increased the participation of students with disabilities in general assessments from $30 \%$ in $2000-2001$ to $98 \%$ in 2003-2004. The state of New Hampshire reports $100 \%$ participation of students with disabilities in general assessments.

Students with the most significant cognitive disabilities are also included in NCLB's assessment scheme via alternate assessments aligned to alternate achievement standards. Alternate assessments are intended for students who are unable to participate in the general education assessments even with accommodations or modifications. In 2003 the Department of Education provided guidance to states that allow them to develop alternate assessments for students with the most significant cognitive disabilities; however, only $1 \%$ of all students assessed in the grade may be considered as "passing." This cap was based on an analysis of the percentage of students with significant mental retardation and other disabilities that impair intellectual functioning in a significant way. This is roughly equivalent to 10 percent of all students with disabilities (USDOE, 2004). Many states include students who have autism, moderate to severe mental retardation, multiple disabilities, and traumatic brain injury in the alternate assessment category for accountability (Rabinowitz et al., 2008).

One of the most important changes that NCLB has mandated is that states must link the alternate assessments for students with significant cognitive disabilities to alternate standards that are aligned with general education standards (Rabinowitz et al., 2008). This mandate has presented great challenges as states embark on developing assessments that can be implemented efficiently and comparably across states. Given the range in cognitive abilities of students who take alternate assessments, a one size fits all alternate assessment will not work. In the year 2004-2005, all 50 


\section{Participation of Special Education Students in General Assessments in Selected States, 2000-2001}

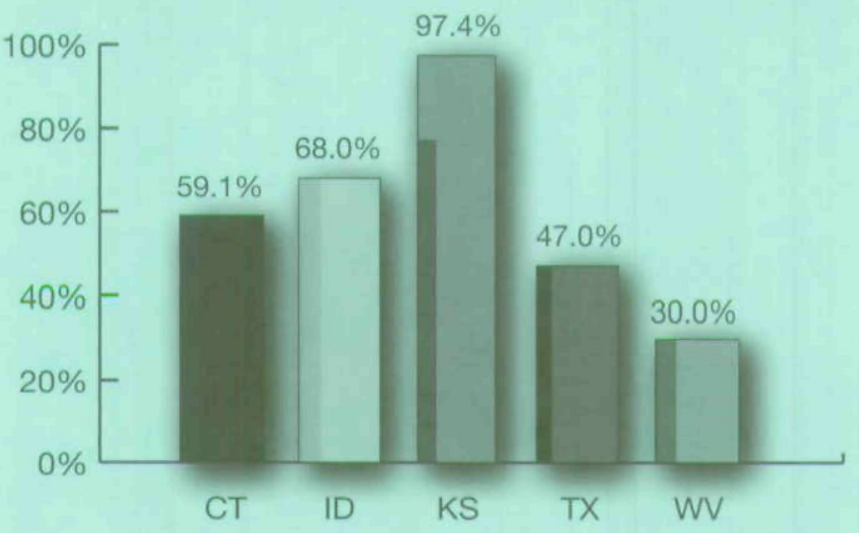

Participation of Special Education Students in General Assessments in Selected States, 2003-2004

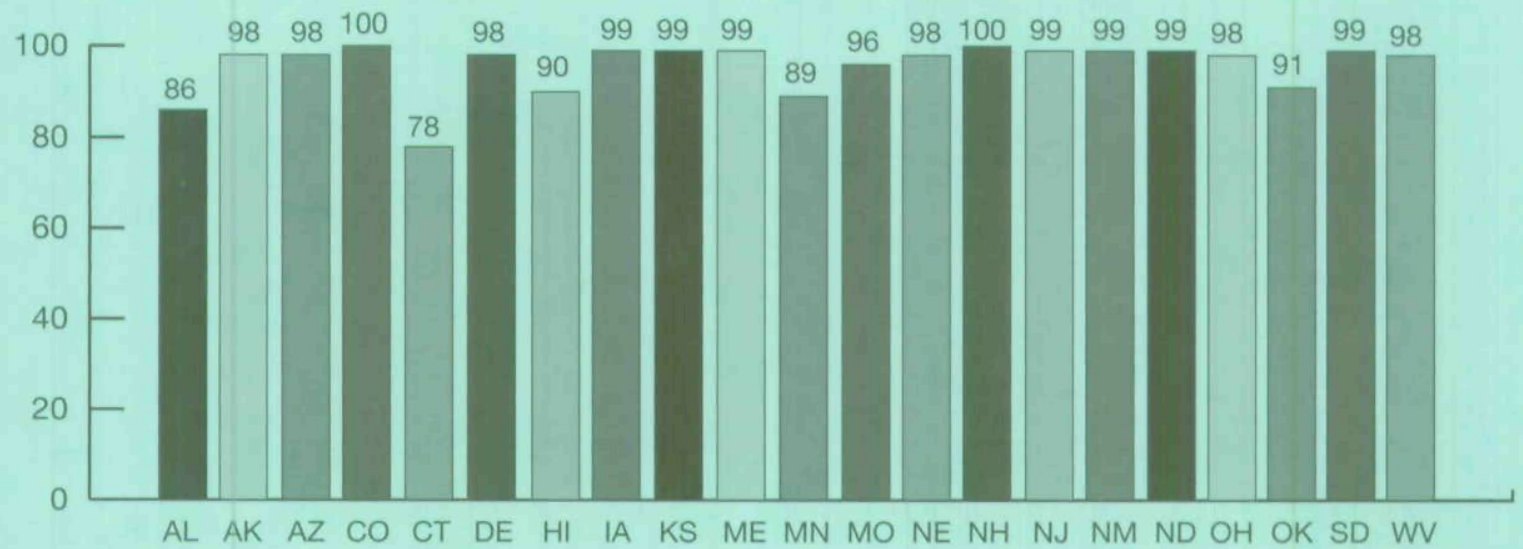

Source: Rewards \& Roadblocks: How Special Education Students are Faring Under No Child Left Behind (10-11), by C. Cortiella, 2007, New York: National Center for Learning Disabilities.

FIGURE 3

Participation in General Assessments 2000-2001 and 2003-2004

states reported some disaggregated data for students with disabilities, including alternate assessment data (VanGetson \& Thurlow, 2007). There has been a clear increase in the participation of students with disabilities in statewide assessments, including students with significant disabilities (Rabinowitz et al., 2008).

As a result of being included in assessments and counting towards the success of a school's performance, children with more significant disabilities have had an increased focus placed upon their educational needs. If students are assessed in alignment with general education standards, curriculum for students with significant disabilities needs to address the standards. Curriculum alignment for students with significant disabilities remains a challenge for states. However, there has been an increase in changes made to the curriculum for students with significant cognitive disabilities to include alignment with the general education standards (Rabinowitz et al., 2008). Examples of alignment include increasing literacy and communication skills (for reading) and increasing functional skills such as doing laundry, cooking, and shopping (for math). Integrating academic and functional skills can be an effective approach in teaching students with significant cognitive disabilities (Thompson, Johnstone, Thurlow, \& Altman, 2005). 
Dymond, Renzaglia, Gilson, and Slagor (2007) conducted a study to determine how both special educators and general educators defined access to the curriculum for students with significant cognitive disabilities. They found general educators defined access as receiving the same curriculum in the general education setting with support from special educators, while special educators defined access to the general education curriculum as adapting the curriculum to meet the needs of students and to develop skills to enhance a student's life. Both general educators and special educators believed that the general educators' involvement is needed, as the general educator is the expert in content, and that special educator involvement is needed, as the special educator is the disability and pedagogy expert. In order to increase access to the general education curriculum for students with significant cognitive disabilities, both general educators and special educators believed that collaboration is the key to success. Only through access to the general education curriculum can students with disabilities be expected to achieve high academic standards.

In summary, access to the general education curriculum for students with disabilities has improved under NCLB. More students are being assessed with district and statewide assessments. Students with significant cognitive disabilities are included in accountability measures via alternate assessments aligned to alternate achievement standards, which are linked to the general education curriculum. More students with disabilities are receiving instruction in general education classrooms than ever before.

\section{NCLB'S CONTRIBUTION TO INCREASING THE ACHIEVEMENT OF STUDENTS WITH DISABILITIES}

As a direct result of NCLB, for the first time in the history of special education, schools and districts must assess, report, and confront the achievement gap of children with disabilities. Because of the low performance of students with disabilities initially (and in some cases continuing) some schools and districts have felt punished for the lack of progress students with disabilities were able to make. However, more recently the performance of students with disabilities under the mandates of NCLB has demonstrated that children with disabilities can achieve high standards if expectations are put in place, if students are taught the curriculum, and if students have the supports and accommodations they require.

The outcomes of NCLB for students with disabilities have shown that students with disabilities can meet high standards with proper instruction and assessment (Commission on No Child Left Behind, 2007). Van Getson and Thurlow (2007) conducted a research study for the National
Center on Educational Outcomes on the public reporting of state assessment results of students with disabilities. The purpose of the study was to analyze the participation and performance data across states. In the 2004-2005 school year, all 50 states reported on the percent of students with disabilities who scored proficient on general assessments, and 40 states reported the number of students with disabilities in each achievement level. Forty-two states reported the percent of students with disabilities that were proficient on alternate assessments, and 27 states reported the number of students with disabilities on each alternate assessment achievement level.

The authors found that significant achievement gaps exist between students with disabilities and their nondisabled peers on general education assessments. The achievement gap widens at higher grades. More students scored proficient on alternate assessments compared to general assessments. The widening of the achievement gap was not present in the alternate assessment performance data.

A December 2008 statement issued by the U.S. Department of Education noted that children once left behind have made great strides forward. It sites an improvement of 23 points in the average reading scores for fourth grade students with disabilities between 2000 and 2007. (USDOE, 2008b).

An examination of NAEP data for students with and without disabilities spanning 1998 to 2007 (See Figure 4) clearly shows how much further behind students with disabilities are than students without disabilities. However, the chart also demonstrates the impressive gains students with disabilities are making. The rate of improvement in both reading and math and for both grades 4 and 8 is greater or about the same for students with disabilities than it is for students without disabilities. For example, in grade 8 mathematics, there was a $17 \%$ increase in the percentage of students with disabilities scoring proficient or advanced while there was an $11 \%$ increase for students without disabilities. In grade 4 reading, there was an $11 \%$ increase for students with disabilities scoring at the proficient or advanced level and an $8 \%$ increase for students without disabilities. NAEP offers a more reliable assessment of the progress of students with disabilities than state tests, as all students who participate in NAEP take the same test while students in different states take different tests aligned to different standards.

A troubling concern that NCLB has raised is the increase in the drop out rate since NCLB's enactment. Since the inception of NCLB, graduation and certificate of completion rates have increased; however, dropout rates for students with disabilities remains a significant concern (see Figure 5).

The disparity in success for students with disabilities in different schools and school districts is a topic of keen interest. Why, in some schools, are students with disabilities 


\section{Mathematics}

\section{GRADE 4}

GRADE 8

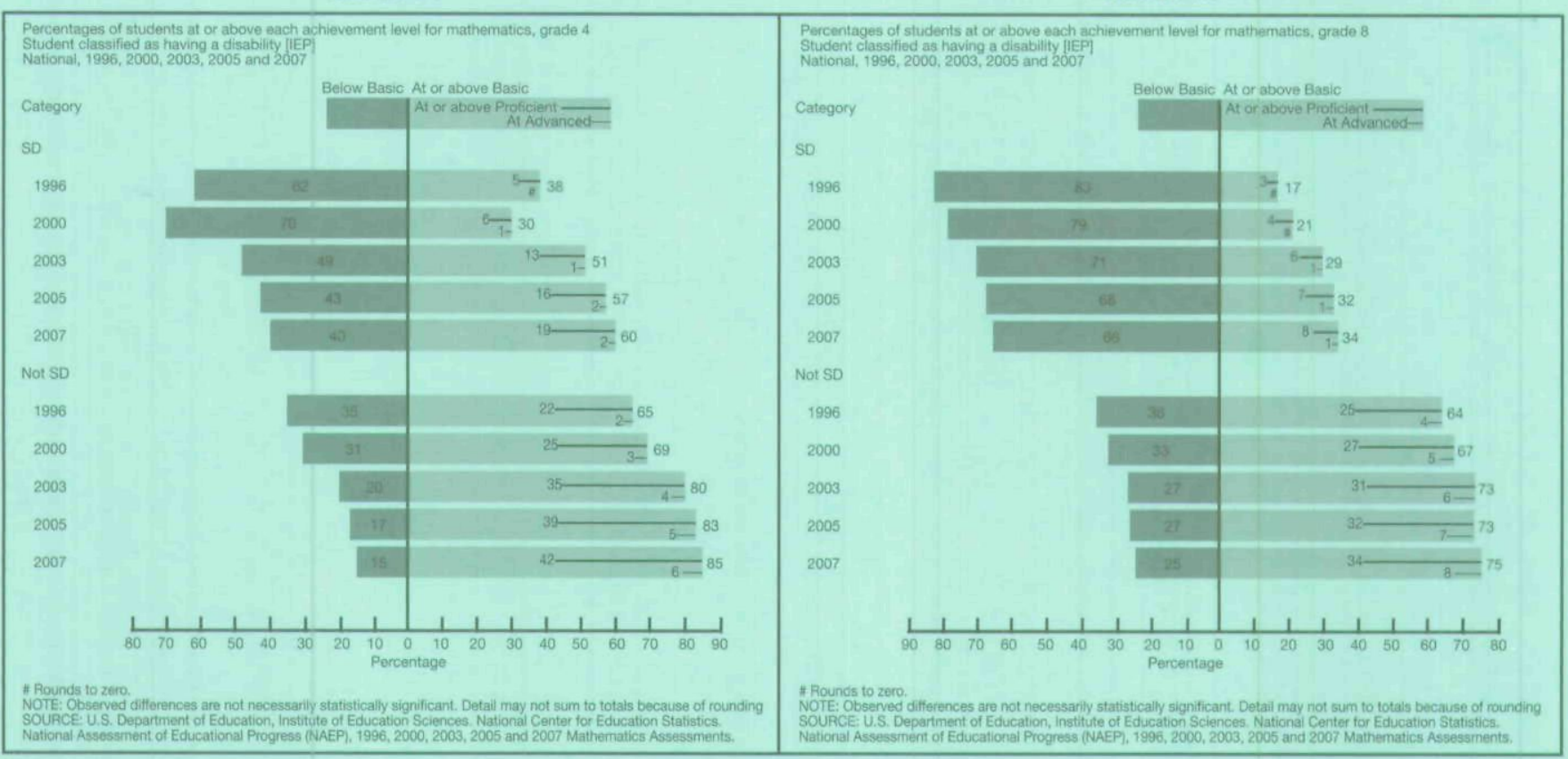

\section{Reading}

GRADE 4

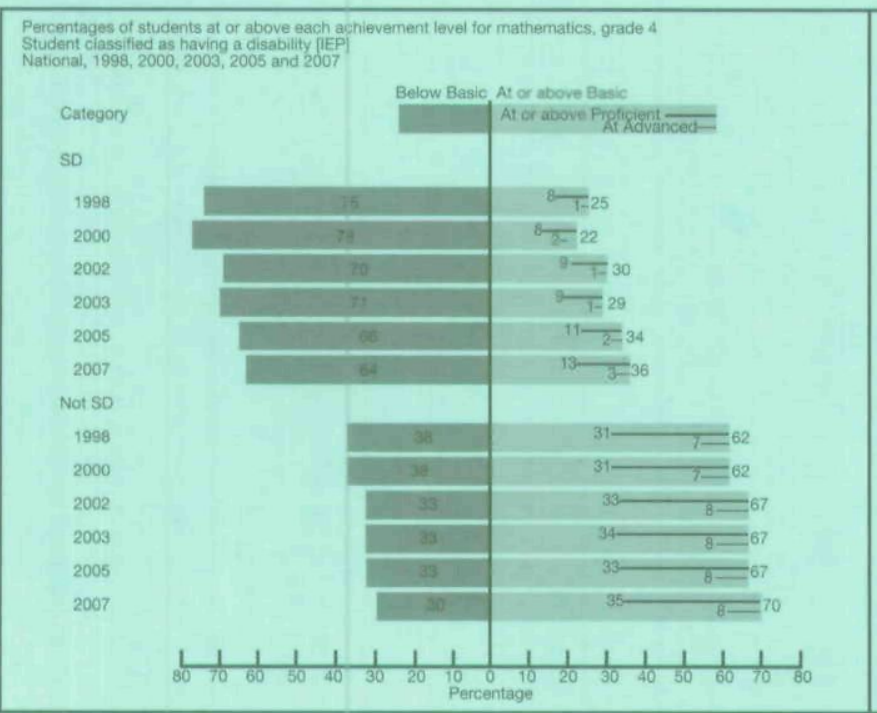

GRADE 8

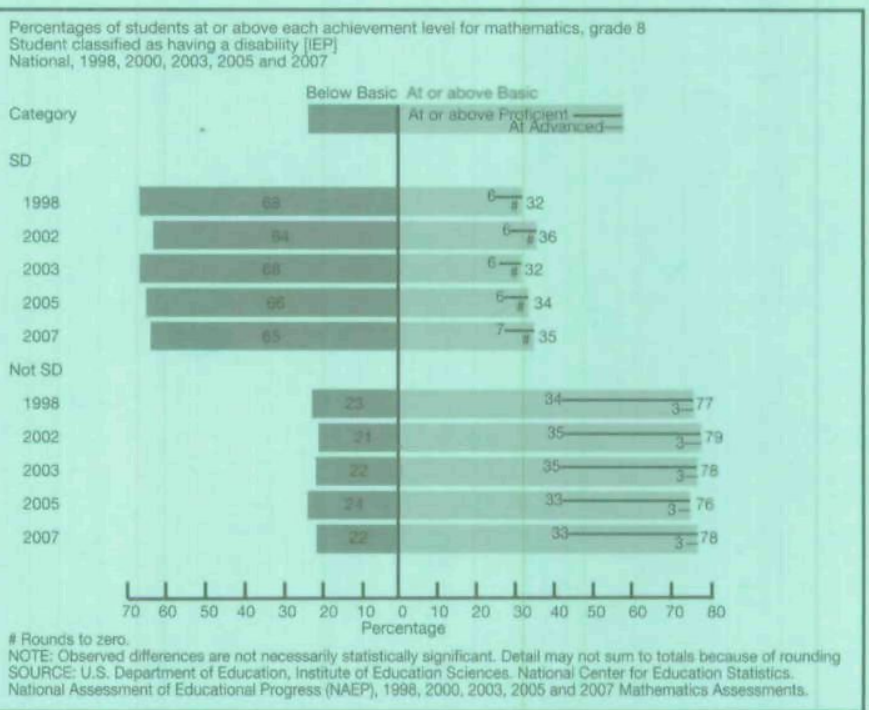

Source: NAEP Assessment: Performance of students with disabilities, 1998-2007, by L. Kaloi, 2007, New York: National Center for Learning Disabilities. 


\section{Students with Disabilities: Diplomas, Certificates and Drop Outs}

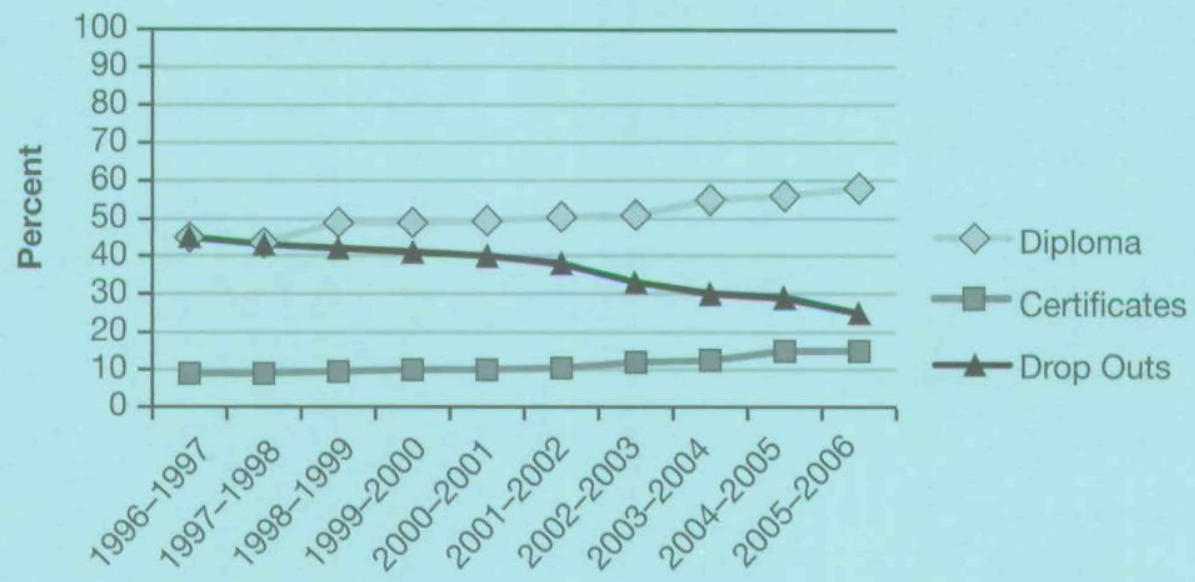

Source: The Condition of Education 2008 (NCES 2008-031), by M. Planty, W. Hussar, T. Snyder, S. Provasnik, G. Kena, G. Kena, et al., 2008, Washington, DC: National Center for Education Statistics, Institute of Education Sciences, U.S. Department of Education.

\section{FIGURE 5}

\section{Graduation, Certificates and Dropouts}

performing relatively well and in others they are not? One study concludes that success for students with disabilities in academic achievement depends upon their access to the general education curriculum and the capacity of educators to teach to a diverse population (Nagle, Yunker, \& Malmgren, 2006). Malmgren, McLaughlin, and Nolet (2005) conducted a study to determine the school level factors that contribute to the overall performance of students on statewide accountability assessments. The authors investigated the impact of three school-level variables: demographic characteristics, school characteristics, and special education characteristics. The authors found that the single best predictor of school academic performance is related to a "school effect." In other words, if general education students achieve high academic standards, so will everyone else in the school. This conclusion supports access to the general education curriculum and participation in general education classes by students with disabilities. Furthermore, it challenges the notion that differences in student performance between students with and without disabilities are the inherent result of the disability, rather than other factors, such as quality of instruction and access to the general education curriculum.

Perhaps the most significant finding to date regarding the achievement of students with disabilities comes with more recent data, which demonstrate that the performance of students with disabilities, in some cases, is distributed across the achievement continuum. In other words, the lowest performers in schools and districts are not necessarily students with disabilities, and some students with disabilities are among the highest performers. Figure 6 shows that the students in the lower left quadrant of the graph (the lowest performing students) are both students with and without disabilities. Furthermore, students with disabilities are distributed throughout the achievement continuum.

These data and others fly in the face of the logic behind the " $2 \%$ policy" developed by the U.S. Department of Education. The $2 \%$ option was published as a regulation on April 9, 2007 (34 CFR Part 200). States may elect to use this option which involves developing modified academic achievement standards for up to $2 \%$ of all students (however, the students must also be special education students) and developing alternate assessments aligned to these modified standards. Two percent of all students translates to $20 \%$ of students with disabilities who are served under IDEA. The $2 \%$ option is for students whose disability precludes them from achieving grade-level proficiency and who are not likely to achieve grade-level proficiency in the coming year. To date, eight states have administered alternate 


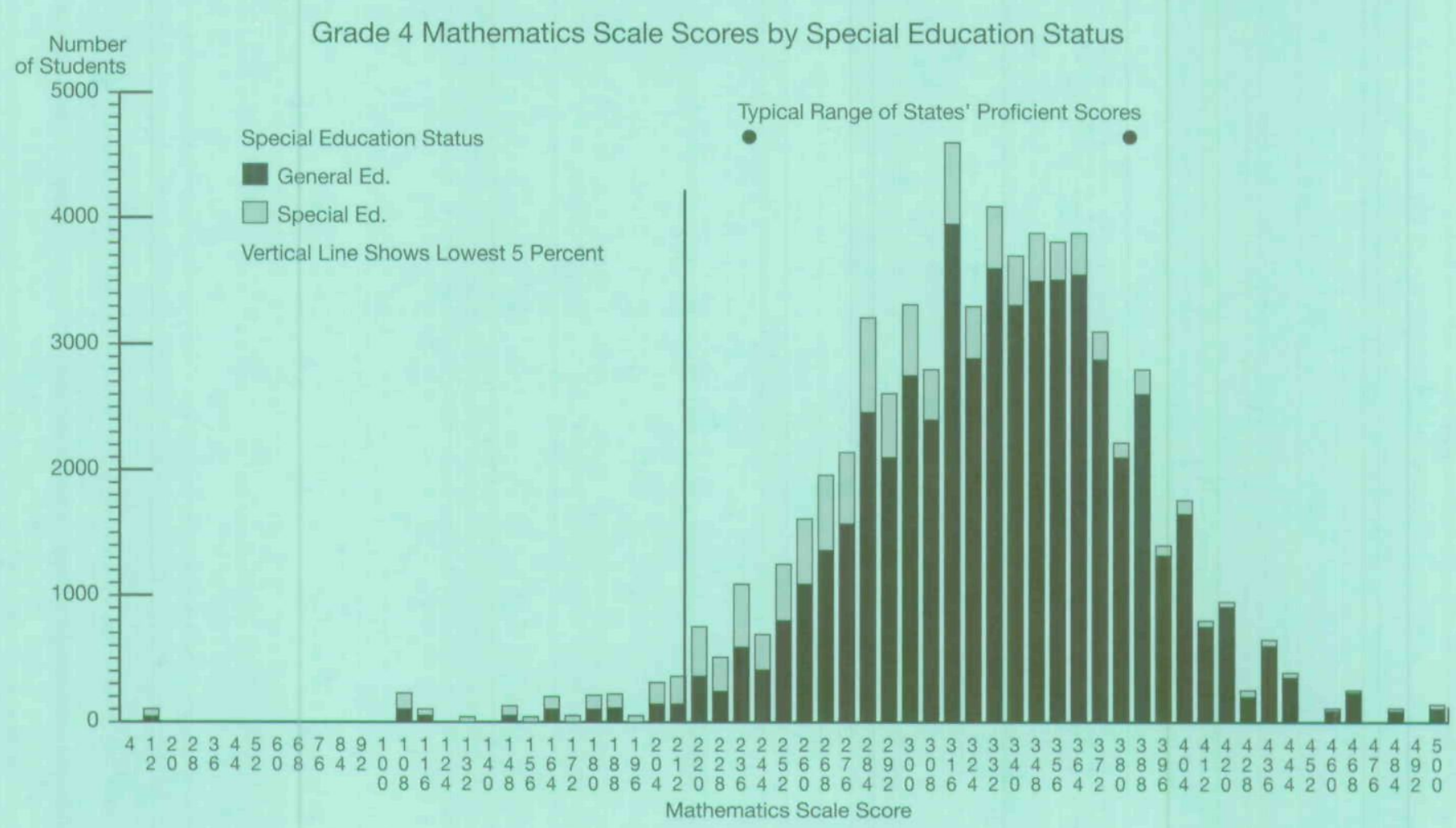

Source: Rewards \& Roadblocks: How Special Education Students are Faring Under No Child Left Behind (15), by C. Cortiella, 2007, New York: National Center for Learning Disabilities.

FIGURE 6

Lowest $5 \%$ of Academic Performance Grade 4 Mathematics: Special and General Education

assessments aligned to modified academic achievement standards. An additional 20 states have indicated that they are working on developing these assessments. Many of these states have chosen the option of waiving into the proficient category up to $20 \%$ of students with disabilities based on the fact that they are working on developing the modified standards and alternate assessments (USDOE, 2009).

Georgia and Colorado are two states that have been using performance data to analyze the achievement levels of students with disabilities and to inform policy development. When considering whether or not to adopt the $2 \%$ policy option, Colorado analyzed reading and math scores in grades 3-10. They determined that not all of the students performing in the lowest one third on state assessments were students receiving special education services, which led them to ask why students with disabilities were singled out for modified achievement standards. They determined that accommodations were not consistently provided to all eligible students, and they noted substantial longitudinal growth toward grade level achievement for most students over time. (HB 05-1246 Study Committee, 2005). Colorado decided not to pursue the $2 \%$ option.

Georgia has been analyzing the statewide test results for students in math and reading with an eye toward better understanding the composition of the group of students who are "low performing" (lowest performance level in at least 1 assessment), "persistently low performing" (lowest performance level for 3 consecutive years), and "consistently low performing" (consistently low performing in both subjects). Their initial analysis indicates that of all students who are designated as persistently low performing, between $40 \%$ and $55 \%$, are students with disabilities. Therefore, between $60 \%$ and $45 \%$ of persistently low performing students are not students with disabilities (Dunn, 2008). Again, these data challenge the logic of the $2 \%$ policy, which implies that 
only students with disabilities will be the lowest performing students and that the disability of a student serves to impair academic performance in a manner that is intractable. ${ }^{2}$

\section{THE PATH FORWARD}

It has been almost 8 years since the enactment of NCLB. The implementation of the law in relation to students with disabilities has been one of the most controversial and challenging aspects of a law that has galvanized supporters and detractors alike in a manner akin to a longstanding family feud. Framers of the legislation were not equipped to give thorough consideration to how school districts and schools would shift from a focus on ensuring access to education for students with disabilities to mandated accountability for the learning of students with disabilities to the same high standards as all other students. The transition has been challenging. The policy community has had to confront tough questions (How exactly do disabilities limit student learning? How can we be sure it is the disability and not the quality of instruction or lack of modifications or supports and services that is impeding learning?) and schools and districts have had to face significant capacity limitations (lack of knowledge and skill related to creating alternate assessments, alternate standards and modified standards, lack of knowledge and skills regarding how to utilize universal design to create statewide assessments, lack of sound policy on accommodations, lack of adequate funding, lack of highly qualified personnel).

The fact that NCLB enabled data on the achievement of students with disabilities to become available has been a significant contribution to the analysis and development of education policy. As we move toward the reauthorization of NCLB, we must be sure to use these data to inform our policy options. Opportunities for progress and risks of regression are plentiful. We offer the following recommendations.

\section{Retain Students With Disabilities as a Subgroup}

The fact that NCLB requires the achievement levels of students with disabilities to be reported as a subgroup is a critical component of progress for students with disabilities. The new data generated by this provision have raised awareness and generated very important questions among experts, policy makers, and advocates. For the first time, we have data to document the achievement gap and a data set to use as a benchmark in pursuing progress. Without achievement data, there would be no comprehensive way to measure

${ }^{2}$ The original draft regulation for the $2 \%$ policy described students eligible for this category as "persistently academically deficient." Advocates balked at this term and it was dropped from the final regulation. progress. Accountability data also allow for the comparison of achievement rates among schools, school districts, and states. It is now possible to investigate why students with disabilities from one school or district are outperforming students with disabilities from another school or district. Analysis of data about low performing students across all subgroups also offers critical opportunities to consider effective interventions.

\section{Include Students With Disabilities, Including Students With Significant Cognitive Disabilities in all Accountability Measures}

What gets counted gets attention. For the first time, under NCLB, the achievement of students with disabilities has been counted. Schools, school districts, and states became responsible for the achievement of students with disabilities. This has been a challenging transition fraught with barriers of capacity, resources, and beliefs. The accountability for the achievement of students with disabilities represents a fundamentally different way of doing business. It is important to acknowledge that change of this magnitude takes time and investment. Turning away from the full inclusion of students with disabilities in accountability systems because it is too hard would neither be in the best interest of students with disabilities nor of our nation. Moving forward means continuing to invest in the capacity to design and implement meaningful and effective accountability systems that fully include students with disabilities.

NCLB reauthorization is likely to include further consideration of multiple measures of accountability, such as graduation rates and growth models. A growth model is a system that meets the principles of NCLB by assessing the growth of individual students over time. As of October, 2008 the U.S. Department of Education had given approval for 10 states to pilot growth models. It should be noted that several of the pilot growth model systems do not include students who take alternate assessments. It will be critical for growth models to develop the capacity to include all students with disabilities to ensure that their progress is appropriately captured and that the accountability mechanism is robust. Accountability measures and requirements for highly qualified teachers have had a clear impact on access to the general education curriculum for students with disabilities, and they should be retained. Students with disabilities should be included in graduation rate calculations without lowering expectations for them.

\section{Rethink the "2\%" Policy}

The reauthorization of NCLB is an opportunity to rethink the challenge of assessing low performing students in a manner that is more integrated with the fabric of NCLB and driven by achievement data rather than by disability label. 
Data are now available that indicate that the lowest performers in many schools are not necessarily students with disabilities. If the lowest performing students are not just students with disabilities, why do we factor out of this category for an alternate assessment tied to modified standards only students with disabilities?

The $2 \%$ policy is based on the belief that a disability is the cause of the low performance. This logic must be challenged. There is no scientific evidence to suggest that $20 \%$ of students with disabilities will be precluded from achieving grade level performance by their disability. When we consider that the students in the $2 \%$ category are not students with significant cognitive impairments (as they are captured in the $1 \%$ group $^{3}$ ), but rather students with learning disabilities, speech/language impairments, visual or hearing impairments, and other health impairments, then we must question why we would develop lower performance expectations for them (See Figure 2). Furthermore, the knowledge that there is a chronic shortage of fully certified special education teachers, that students in urban settings and low socioeconomic areas are more likely to be taught by unqualified teachers, and that general education teachers lack needed skills to instruct students with disabilities (National Comprehensive Center for Teacher Quality, 2008) must be added to the equation. Might it be that at least some portion of the low performance of some students with disabilities is the result of inadequate access to effective teachers? Additionally the low level of funding for both NCLB and IDEA may result in a lack of access to needed supports and services for students with disabilities, which may lead to lower academic performance. Finally, the limited compliance of states with IDEA may influence student achievement. In 2000 , no states were $100 \%$ in compliance with IDEA (NCD, 2008), and only nine states were "on track" to meet IDEA compliance indicators (Wright, 2007).

A more rational $2 \%$ policy would intervene with targeted services for all students who are the lowest performing, rather than strictly for the portion of low performing students who have disabilities. Rather than singling out a low performing group for a different assessment, why not intervene with additional services for all members of the low performing group? Indeed, imagine the outcry if a portion of students from a particular ethnic minority group were singled out to take an alternate assessment tied to modified achievement standards! As Florian (2007) noted, while special education

\footnotetext{
${ }^{3}$ On Dec. 9, 2003 the U.S. Department of Education issued final regulations allowing states to establish alternate achievement standards for students with significant cognitive disabilities. These standards can be used in determining proficiency for up to $1 \%$ of the total population of students tested when calculating Annual Yearly Progress under NCLB.
}

practices are intended to achieve equal educational opportunity, they may become perpetuators of injustice in education. The $2 \%$ policy needs to be examined with this consideration in mind.

Discussions about the $2 \%$ policy during the 2007-2008 efforts to reauthorize NCLB were generally focused on how big the " $2 \%$ " number should be. In other words, how many students with disabilities should be assessed using alternate assessments benchmarked to modified achievement standards? The draft issued by the U.S. House of Representatives Committee on Education and Labor (2007) called for waivers that would allow up to $3 \%$ of students (or $30 \%$ of students with disabilities in addition to the $10 \%$ with significant cognitive disabilities) to be assessed according to modified standards. Some education organizations have called for all students with disabilities to be outside of the NCLB accountability system. They argue that all students with disabilities should be held accountable via their IEP. The IEP is not designed to address overall academic achievement, however, as it addresses only the individualized disabilityrelated needs of the students and not all of the academic areas. For example, a student with speech-language impairment may only have communication or language development goals on his or her IEP. The IEP would not indicate standards based performance levels or allow achievement gap data to be collected.

Achievement data should be used to drive new policy solutions that are more closely tied to bringing all students to proficiency and less interested in separate interventions for students with disabilities. An increased investment in capacity of teachers, universally designed instruction and assessment and supports and services, rational accommodations policy, along with a $2 \%$ policy that calls for additional targeted intervention for all low performers, would be preferable to the current $2 \%$ policy in light of NCLB's goal to bring all students to proficiency.

\section{Fully Fund IDEA and NCLB and Increase Infrastructure Investments}

In order to meet the requirements of NCLB and IDEA, significant additional funding is necessary. Both laws have been significantly underfunded for years, and that must change. The federal government's promise to fund $40 \%$ of the excess cost of IDEA needs to be met, in keeping with President-elect Obama's campaign promise. This represents more than a doubling of the funding, as FY 2008 spending represented $17.1 \%$ of the excess cost of educating students with disabilities.

More robust technical assistance is needed for states to strengthen their data collection systems and particularly their data analysis capacity. Only with technical assistance will states be able to develop effective growth model systems and 
data collection systems to adequately measure student progress. Other needed investments in capacity include the development of general education personnel who are proficient in educating students with disabilities, the development of more highly qualified special education teachers, the development of universally designed assessments, and the development and deployment of additional research based inclusive practices. Finally, it is crucial that states develop sound accommodations policies.

\section{Further Integrate IDEA and NCLB}

Students with disabilities are first and foremost general education students. The President's Commission on Excellence in Special Education summed this position up as follows in their 2002 report, "A New Era: Revitalizing Special Education for Children and Their Families":

\begin{abstract}
Children placed in special education are general education children first. Despite this basic fact, educators and policymakers think about the two systems as separate and tally the cost of special education as a separate program, not as additional services with resultant add-on expense. In such a system, children with disabilities are often treated, not as children who are members of general education and whose special instructional needs can be met with scientifically based approaches, they are considered separately with unique costs - creating incentives for misidentification and academic isolation - preventing the pooling of all available resources to aid learning. General education and special education share responsibilities for children with disabilities. They are not separable at any level—cost, instruction or even identification.
\end{abstract}

Johnson (2003) has argued that the concept of the provision of FAPE, a core tenet of IDEA, must be revisited in light of 1997 amendments to IDEA and NCLB requirements for students with disabilities. Twenty years ago, in Hendrick Hudson Central School District Board of Education v. Rowley, the U.S. Supreme Court held that FAPE requires that services to students with disabilities must provide them with "some educational benefit." Clearly NCLB policy anticipates a far more stringent standard for students with disabilities, namely, meeting rigorous state standards. Johnson argues that it is time to revisit the parameters of FAPE and clarify that the provision of "some educational benefit" is not adequate in an era where all students are expected to reach proficiency by a date certain.

Numerous provisions were included in the 2004 reauthorization of IDEA that integrate it with NCLB requirements. The definition of a highly qualified teacher was extended to special education teachers, and funds were identified that could be used for general education students struggling behaviorally or academically, distinct from students in special education. Sound educational practices, which were developed with students with disabilities in mind but have school-wide application, are expanding, such as Responsiveness to Intervention and the use of Positive Behavioral Supports. Examining these two laws in tandem with an eye toward better integrating them will result in policy that limits conflicting requirements and better addresses the needs of all students.

\section{CONCLUSION}

Federal policy has been a positive driving force for students with disabilities, their families, and special education in the last four decades. There is no question that people with disabilities are better off in American society today than they were in 1975. IDEA's contribution to this improved quality of life is enormous.

Early outcome evidence from NCLB offers much promise for students with disabilities; however, because NCLB fundamentally alters expectations for students with disabilities without providing a meaningful investment in capacity building, it has been challenging for schools and districts to implement effectively. The crossroads presented by the impending reauthorization of NCLB offers a choice of continuing down a path of high expectations, accountability, and data driven decision making or regressing backward toward an environment where outcomes for students with disabilities are less important than access. We recommend continuing down the path of high expectations, accountability, and data-driven decision making.

\section{REFERENCES}

Brown v. Board of Education, 347 U.S. 483 (1954).

Chubbs, J. E., (Ed.) (2005). Within our reach: How America can educate every child: An assessment by the Hoover Institution's task force on $K-12$ education. Lanham, MD: Rowman and Littlefield.

Cole, C. (2006). Closing the achievement gap series: Part III What is the impact of NCLB on the inclusion of students with disabilities. Education Policy Brief, Center for Evaluation and Education Policy, $4(11)$.

Commission on No Child Left Behind (2006). Children with disabilities and LEP students: Their impact on the AYP determinations of schools. Washington, DC: The Aspen Institute.

Commission on No Child Left Behind (2007). Beyond NCLBA: Fulfilling the promise to our nation's children. Washington, DC: The Aspen Institute.

Cortiella, C. (2007). Rewards \& roadblocks: How special education students are faring under No Child Left Behind. New York: National Center for Learning Disabilities.

Dunn, J. (2008). Investigating the academic achievement of persistently low performing students. (Powerpoint presented to the Council of Chief State School Officers) Atlanta: Georgia Department of Education.

Dymond, S. K., Renzaglia, A., Gilson, C. L. \& Slagor, M. T. (2007). Defining access to the general curriculum for high school students with significant cognitive disabilities. Research \& Practice for Persons with Severe Disabilities, 32(10), 1-15. 
Education for all Handicapped Children Act of 1975, 20 U.S.C. section1401 et seq.

Finn, C., Rotherham, A., \& Hokanson, C. (2001). Rethinking learning disabilities, Rethinking special education for a new century. Washington, DC: PPI \& The Thomas B. Fordham Foundation.

Florian, L. (2007) Reimagining special education. In L. Florain (ed.), The Sage handbook of special education. London: Sage.

HB 05-1246 Study Committee (December 31, 2005). Assessing students in the gap in Colorado. Denver: Colorado Department of Education.

Hendrick Hudson Central School District Board of Education v. Rowley (1982). Washington, DC: U.S. Supreme Court.

Hardman, M. L. \& Dawson, S. (2008, Winter). The impact of federal public policy on curriculum and instruction for students with disabilities in the general classroom. Preventing School Failure, $52(2)$

Individuals With Disabilities Education Act of 1990, 20 U.S.C. section 1401 et seq.

Individuals With Disabilities Education Act Amendments of 1997. 105th Congress, 1st session.

Individuals With Disabilities Education Improvement Act of 2004, P.L. 108-446 601 et seq., 118 Stat. 2647.

Johnson, S. F. (2003) Reexamining Rowley: A new focus in special education law. Retrieved December 15, 2008, from www.harborhouse law.com

Malmgren, K. W., McLaughlin, M. L., \& Nolet, V. (2005). Accounting for the performance of students with disabilities on statewide assessments. The Journal of Special Education, 39(2), 89-96.

Mills v. Board of Education of the District of Columbia, 348 F. Supp. 866 (D.D.C. 1972).

Nagle, K., Yunker, C., \& Malmgren K. W. (2006). Students with disabilities and accountability reform. Journal of Disability and Policy Studies, 17(1), 28-39.

National Center for Learning Disabilities (NCLD). (2008). Why students with learning disabilities need NCLB. New York: Author. Retrieved December 15, 2008, from http://www.ncld.org/content/ view/287/456023/

National Comprehensive Center for Teacher Quality and Public Agenda. (2008). Lessons learned: New teachers talk about their jobs, challenges and long-range plans. Washington, DC: Learning Point Associates.

National Council on Disability (NCD). (2008). The No Child Left Behind Act and the Individuals With Disabilities Education Act: A Progress Report. Washington, DC: Author.

No Child Left Behind Act, 20 U.S.C. 6301 et. seq. (2002). PL 107-110.

Pennsylvania Association for Retarded Citizens (PARC) v. Commonwealth of Pennsylvania, 343 F. Supp. 279 (E.D. Pa. 1972)

Planty, M., Hussar, W., Snyder, T., Provasnik, S., Kena, G., Kena, G., et al. (2008). The condition of education 2008 (NCES 2008-031). Washington, DC: National Center for Education Statistics, Institute of Education Sciences, U.S. Department of Education.

President's Commission on Excellence in Special Education (2002). A new era: Revitalizing special education for children and their families. Washington, DC: Author.

Rabinowitz, S., Sato, E., Case, B. J., Benitex, D., \& Jordon, K. (2008). Alternate assessment for special education students in the southwest region states, (Issues and Answers Report, REL 2008-No.044). Washington, DC: U.S. Department of Education Institute of Education Sciences, National Center for Education Evaluation and Regional Assistance, Regional Educational Laboratory Southwest. Retrieved July 14, 2009, from http://ies.ed.gov/ncee/edlabs

Swanson, C. B. (2008). Special education in America: The state of students with disabilities in America's high schools. Bethesda. MD: Editorial Projects in Educational Research.

Thompson, S. J., Johnstone, C. J., Thurlow, M. L., \& Altman, J. R. (2005). 2005 State special education outcomes: Steps forward in a decade of change. Minneapolis: University of Minnesota, National Center on Educational Outcomes.

Twenty Sixth Annual Report to Congress on Students With Disabilities. (2004). Washington, DC: United States Department of Education.

U.S. Department of Education. (2004). No Child Left Behind provision gives schools new flexibility and ensures accountability for students with disabilities, USDOE SPED fact sheet. Retrieved December 1, 2009, from http://www.ed.gov/nclb/freedom/local/ specedfactsheet.html

U. S. Department of Education. (2008a). Budget summary: Special education and rehabilitation services, Section II. B. Overview. Retrieved January 4, 2009, from http://www.ed.gov/about/over view/budget/budget08/summary/edlite-section $2 b$.html\#overview

U.S. Department of Education. (2008b). Progress by our schools and the U.S. Department of Education. Washington, DC: Author.

U.S. Department of Education. (January 8, 2009). Letters to chief state school officers regarding an update on several NCLB cornerstones. State status chart. Washington, DC: Author. Retrieved January 8,2009 , from http:/www.ed.gov/admins/lead/account/corner stones/index.html

U.S. Department of Education, National Center for Education Statistics. (2007). The Condition of Education 2007 (NCES 2007-064), Washington, DC: U.S. Government Printing Office.

U.S. House of Representatives. (2007). Discussion draft of Title I of NCLB. Washington, DC: Committee on Education and Labor, U.S. House of Representatives.

VanGetson, G. R., \& Thurlow, M.L. (2007). Nearing the target in disaggregated subgroup reporting to the public on 2004-2005 assessment results (Technical Report 46). Minneapolis: University of Minnesota, National Center on Educational Outcomes.

Washington Department of Education. (2003). Washington state proposal to ensure successful implementation of No Child Left Behind. Olympia: Author.

West, J. (2005). An opportunity slipping away, Journal of Visual Impairment and Blindness, November, 677-678.

Wright, P. (2007). IDEA report cards: Did your state pass or fail? Wrightslaw. Retrieved on Jan 5, 2009 at http://www.wrightslaw. $\mathrm{com} /$ news/07/idea.report.cards.htm

Yell, M. L., Drasgow, E., \& Lowery, K. A. (2005). No Child Left Behind and students with autism spectrum disorders. Focus on Autism and Other Developmental Disabilities, 20(3) 259-267.

Yell, M. L., Katsiyannas, A., \& Shiner, J. G. (2006). The No Child Left Behind Act, adequate yearly progress, and students with disabilities. Teaching Exceptional Children, 38(4), 32-39. 
Copyright of Focus on Exceptional Children is the property of Love Publishing Company and its content may not be copied or emailed to multiple sites or posted to a listserv without the copyright holder's express written permission. However, users may print, download, or email articles for individual use. 